\title{
MANUFACTURE AND EVALUATION A COMPATIBLE UNIT TO PRODUCE ANIMAL FEED PELLETS
}

\author{
FOUDA, T. $^{1}, 0$.KADDOUR ${ }^{2}$, A. DERBALA ${ }^{1}$, A. HELAL ${ }^{1}$ \\ and K. ABDELMOHSEN ${ }^{3}$
}

1. Fac. of Agric. Tanta Univ.

2. Fac. of Fish wearily, Suiz Canal, Univ.

3. Agr. Eng. Res. Institute, ARC, Dokki, Giza.

(Manuscript received 24 March 2014)

\begin{abstract}
The main objective of this, research was to manufacture and evaluate compatable unit to produce a rabbit feed pellets including mixing and pelleting the formula in one step. The optimum results of this unit were $427.87 \mathrm{~kg} / \mathrm{h}$ production rate , $37.96 \mathrm{~kW} . \mathrm{h} /$ ton energy, requirements , $88.29 \%$ mixing efficiency, $0.671 \mathrm{gm} / \mathrm{cm} 3$ bulk density, $93.21 \%$ pellet durability, $49.01 \mathrm{~N}$ hardiness, and 566.36 die L/D ratio of $5.5: 1,3.5 \mathrm{~min}$ of mixing retention time, and rollers teeth width of $10 \mathrm{~mm}$ and $\mathrm{LE} /$ ton cost using residues formulation including black seed meal.
\end{abstract}

\section{INTRODUCTION}

Rabbit production has potential in developing countries as a mean of supplying cheap high quality animal protein within the shortest possible time.

Animal fead production always care about, pellet quality, the profited of product and mixing and peleting process, balk density, dirability and hardness.

Agricultural residues represent an extreme problem in Egypt facing the people and the state from economic, environmental and healthy aspects and also arable area of generate annually amount of crop residues almost 25-35 million tons, in addition 293 million cubic meter of animal wastes, this amount is consistently increasing yearly, (Ismael 2001).

David (2003) found that a specific rows of die holes, such as the two interior and outside rows, also sometimes are counter bored to greater depths to encourage feed flow through these outer rows of holes to help dies did not wear more evenly. Hasting (2003) limited the operating conditions which effect on the quality of pellets feed as follows: pellet die thickness as related to diameter of hole as factor in pelleted quality, speed of ration should be also considered for each die thickens/hole diameter combination. Mcmullen et. al., (2004) used a laboratory pellet mill to produce pellets from poultry litter. Due to the high mineral content of poultry litter, samples were mixed with $3 \%$ vegetable oil to lubricate the die and to ensure that the pellet die will 
not clog during pelleting. Before passing through the pellet die, the temperature of the litter was increased to $75^{\circ} \mathrm{C}$ by injecting steam and by the use of a heat gun that blew hot air through the litter. Due to frictional heating during pelleting through the $3 / 16(4.76 \mathrm{~mm})$ diameter holes die, the temperature of the pellets exiting the die increased to $85^{\circ} \mathrm{C} \pm 2{ }^{\circ} \mathrm{C}$. after pelleting, the pellets were cooled in an environmental chamber set at $22^{\circ} \mathrm{C}$ and $40 \%$ relative humidity.

Lee et. al. (2005) illustrated that the die design parameters are the length, width, and height. The heat transfer analysis between the cooling die and product is valuable for die design and prediction of product temperature at analog quality during process scale-up. Predicted product temperatures were generally within $68^{\circ} \mathrm{C}$ of the measured values depending on the size of the cooling die, the feed moisture content, and the cooling method. Kaddour et. al. (2006) found that geometrical dimensions of die holes reference is the most important factor influencing extruder machine efficiency and pellets quality. Producing $12 \mathrm{~mm}$ diameter high quality of large animal feed pellets rely the ration components attributes, for that, the high quality extruded pellets made from residues need different die hole specification comparing with that made from standard components. Results show that the optimum machine efficiency appraised by machine productivity, energy requirements and total losses and appraised for pellets quality .

The objectives of this study are to manufacture and evaluation of a compatible unit to produce rabbit feed pellets from black seed meal residue and optimizing operating parameters (retention time, L / D ratio. Roller speed and rollers teath.

\section{MATERIALS AND METHODS}

The experiments were carried out during years 2011and 2012. The compatible unit to produce rabbit feed pellets was manufactured at privet workshop in Zagazig city and evaluated in agriculture engineering research institute workshop in the Cairo.

\section{MATERIALS:}

Composition of the experimental ration:

A rabbit experimental ration was used in the present study, it has the following composition as shown in Table 3: 
Table 3. The composition of residues and stander rabbit rations .

Standard formula

\begin{tabular}{|c|c|}
\hline Ingredients & $\begin{array}{c}\text { Percentage } \\
(\%)\end{array}$ \\
\hline Barley grains & 19.20 \\
\hline Wheat bran & 28.50 \\
\hline Clover hay & 30.90 \\
\hline Soybean meal & 5.00 \\
\hline Corn grain & 11.7 \\
\hline Molasses & 3.00 \\
\hline Limestone & 1.00 \\
\hline Sodium chloride & 0.25 \\
\hline Premix & 0.30 \\
\hline DL Methionine & 0.15 \\
\hline
\end{tabular}

Residues formula

\begin{tabular}{|c|c|}
\hline Ingredients & $\begin{array}{c}\text { Percentage } \\
(\%)\end{array}$ \\
\hline Barley grains & 19.20 \\
\hline Wheat bran & 28.50 \\
\hline Clover hay & 30.90 \\
\hline Black seed meal & 14.13 \\
\hline Corn grain & 2.57 \\
\hline Molasses & 3.00 \\
\hline Limestone & 1.00 \\
\hline Sodium chloride & 0.25 \\
\hline Premix & 0.30 \\
\hline DL Methionine & 0.15 \\
\hline
\end{tabular}

The raw material was prepared using a hammer mill with concave of $2 \mathrm{~mm}$ holes diameter and feed to pellet mill through pre- conditioner to mix it with addition water as pending material, the addition water percentage were $7 \%$, injection in preconditioner in begging and controlled by valve .

The specification of the compatible pellet machine:

The compatible pellet mill machine base was made from $L$ shape steel sections, having dimension of $980 \mathrm{~mm}$ length, $520 \mathrm{~mm}$ width and $980 \mathrm{~mm}$ high as showing in Fig (1). 


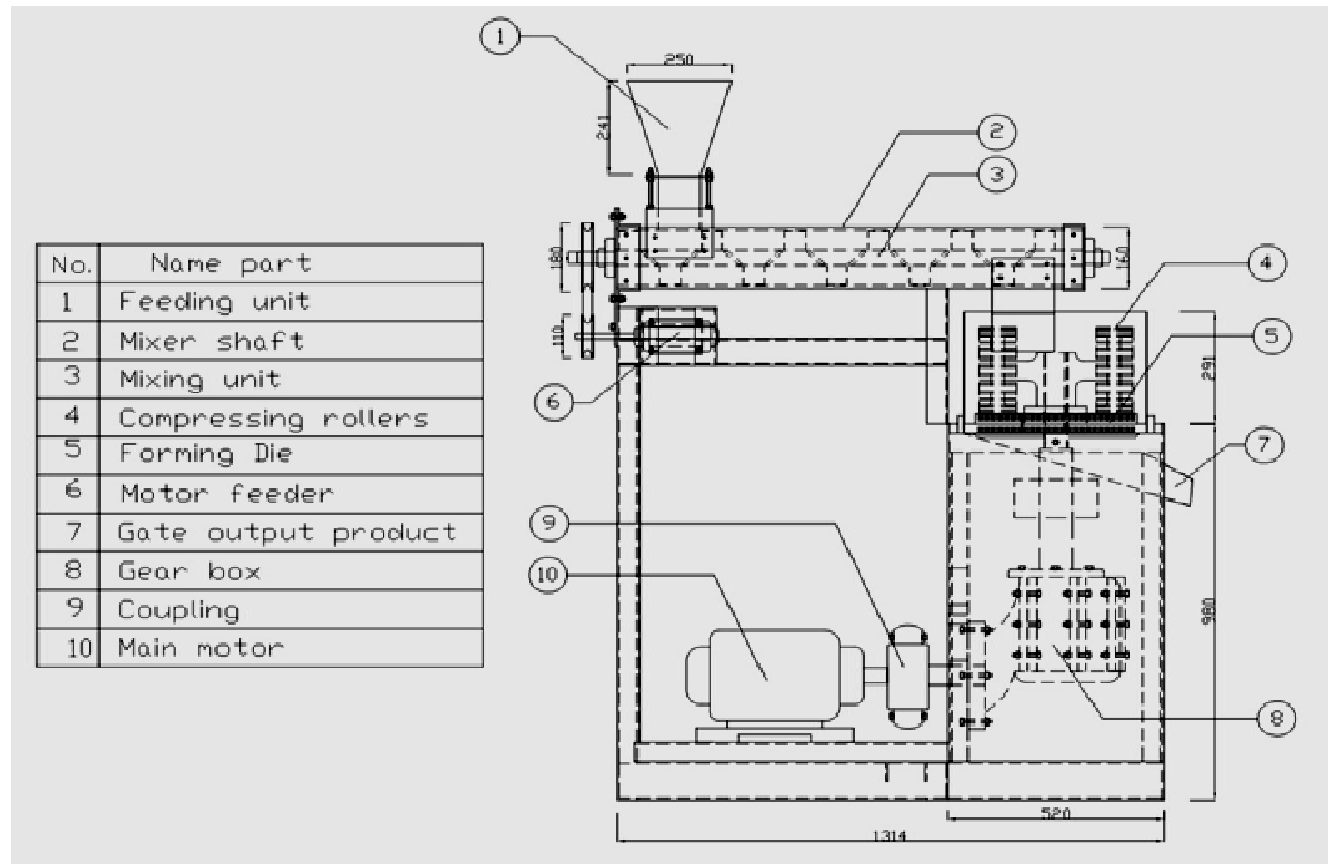

Dim. in $\mathrm{mm}$

Side view

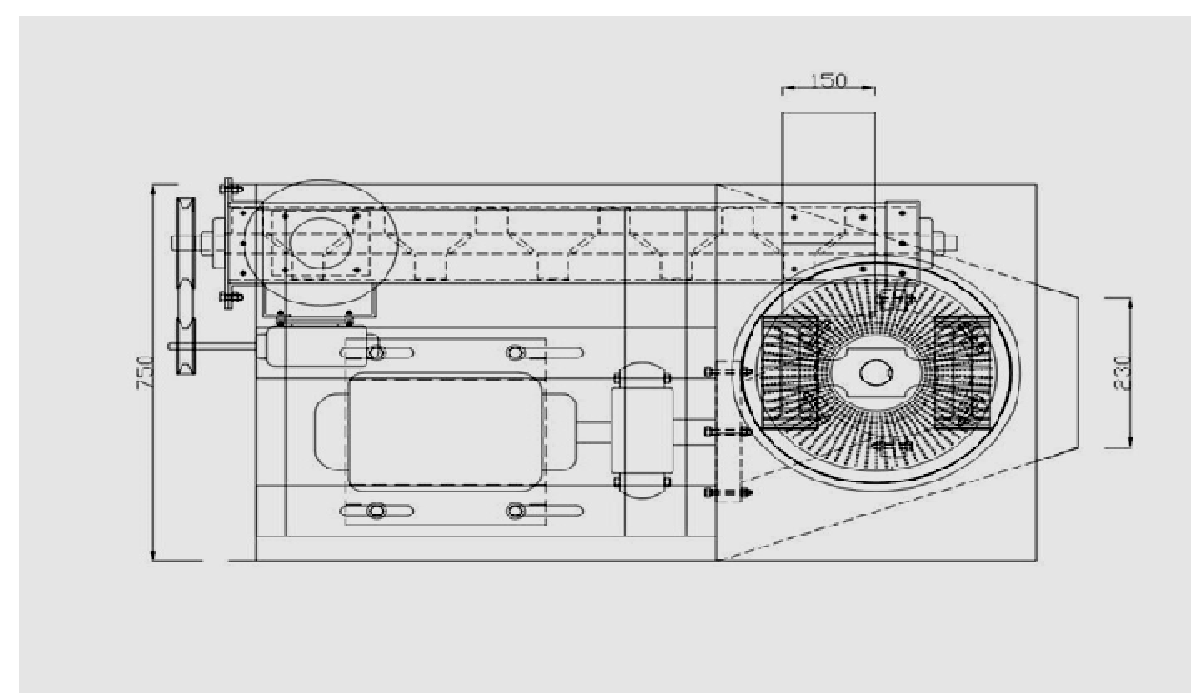

Dim. in $\mathrm{mm}$

Plan view

Fig. 1. Layout of the machine showing different parts.

\section{Feeding hopper:-}

Feeding hopper made from sheet metal, has $2 \mathrm{~mm}$ thickness. It has conical shape; has diameters of $250 \mathrm{~mm}$, and100 mm and $241 \mathrm{~mm}$ high. Transparent cylinder was constructed at the end of the feeding hopper is $80 \mathrm{~mm}$ high as showing in Fig (2) 


\section{preconditioner :-}

The raw materials were transported from feeding hopper to mixer. The pre conditioner as showing in Fig (3) was consisted of:

1- Abarrel:

It had diameter of $170 \mathrm{~mm}$ and length of $1120 \mathrm{~mm}$

2- Mixer shaft

It was designed to transfer and turn the raw material from the beginning of the barrel to the end. The mixer shaft square shape dimensions were $40 \times 40 \times 1100 \mathrm{~mm}$, and each of its end cylindrical shaft has cycle shape with diameter of $200 \mathrm{~mm}$.

3- Pieces of iron sheet

It had square-shaped installed on a mixer shaft, it is working to move raw material from the beginning to the end of

4- The mixer cylinder.

Power transmission of pre conditioner :-

Power was transmitted from Pulley on the shaft of the motor, which has 110 $\mathrm{mm}$ diameter, to Pulley on the shaft of the mixer shaft which has $180 \mathrm{~mm}$ diameter by v. belt section . 

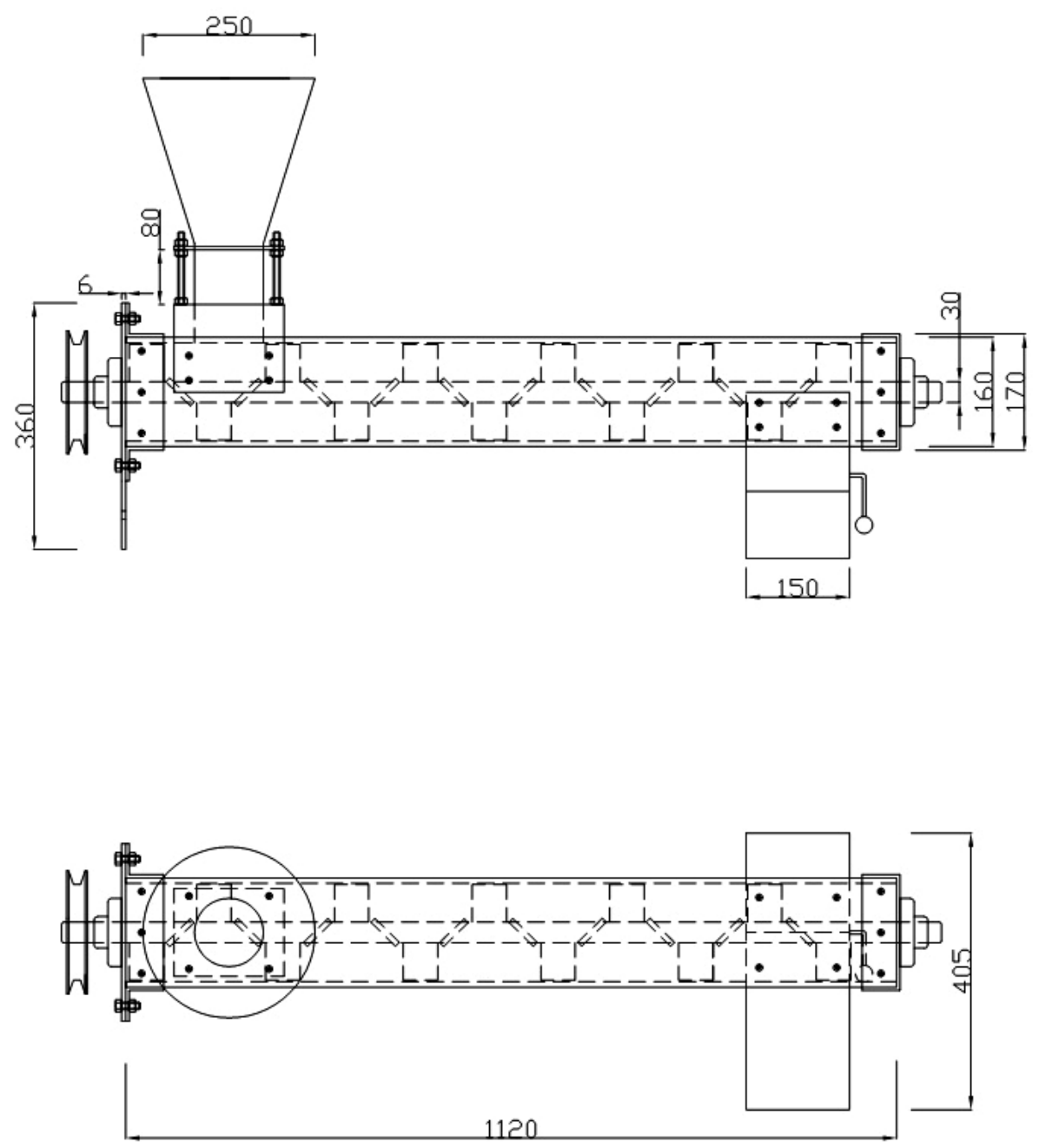

Dim. in $\mathrm{mm}$

Elevation and plan view.

Fig . 2. Pelleting machine feeding unit.

\section{Forming unit (Die):-}

The flat die consider the most important part in disk pellet mill machine. It is responsible to form the patch to pellets with the required diameter. The die material makes from very hard steel 52, it has dimension of $440 \mathrm{~mm}$ outer diameter and 50 $\mathrm{mm}$ inner diameter and thickness of $50 \mathrm{~mm}, 4 \mathrm{~mm}$ diameter circular openings, as shown in Fig (3). 

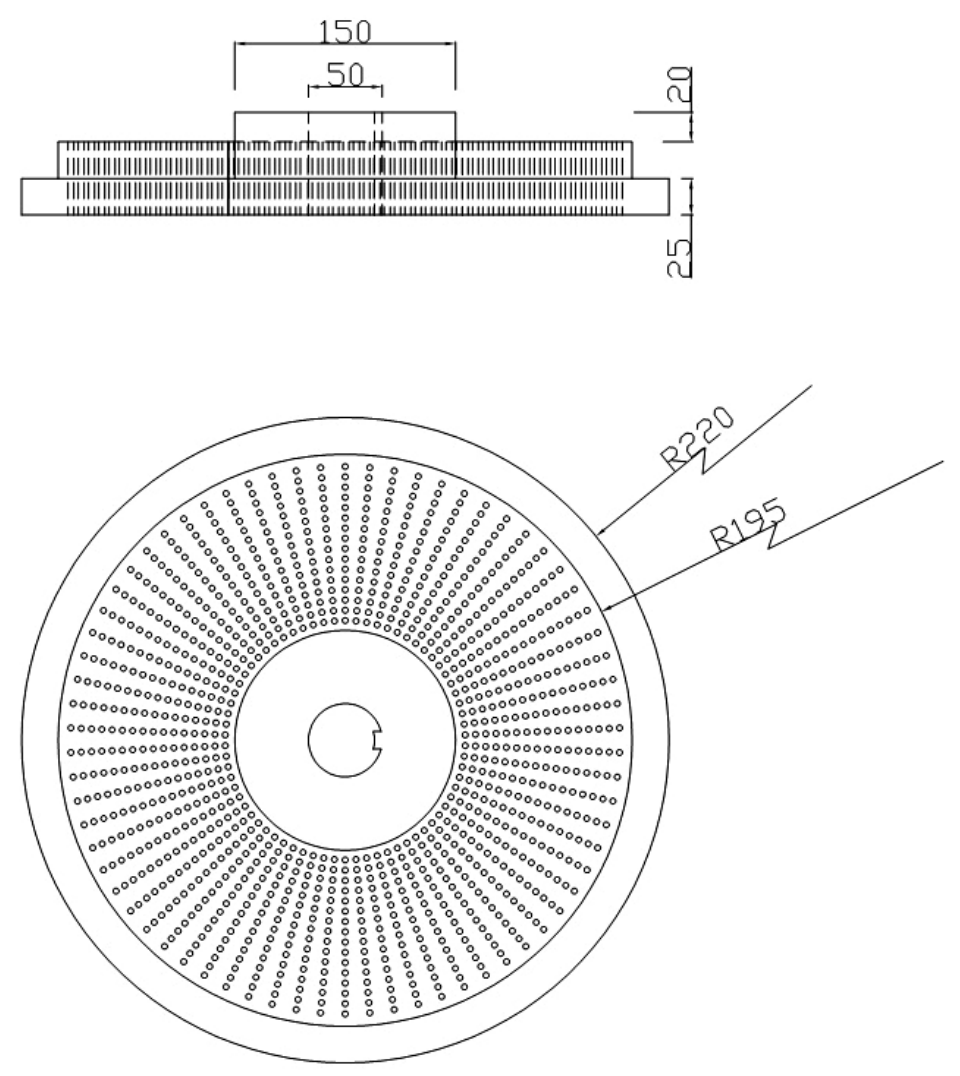

Dim. in $\mathrm{mm}$

Elevation and plan view

Fig. 3. Forming unit (Die).

\section{The compressing unit (Rollers) :-}

The compressing unit is responsible to compress and form the patch to pellets through the die holes. It consists of two rollers, both rollers are fabricated from high carbon steel and constructed by conical bearings on two horizontal bars which fixe on the center iron block. The compressing unit constructed on the top main moving shaft passing through the center of fixed die machine. Each of rollers is cylindrical in shape with the rollers cam base has dimension of $225 \mathrm{~mm}$ outer diameter, $50 \mathrm{~mm}$ innerr diameter and $90 \mathrm{~mm}$ width, the rollers unit constructed on the main shaft by keyway. , the rotating motion of the rollers is stable motion around the horizontal bars which yields from the main shaft rotating motion. There is clearance between the die and the rollers is $0.5 \mathrm{~mm}$ extended according to the motion of the rollers around the horizontal bars for agreement with capacity of raw materials to force pressing through the die holes as shown in Fig (4). 

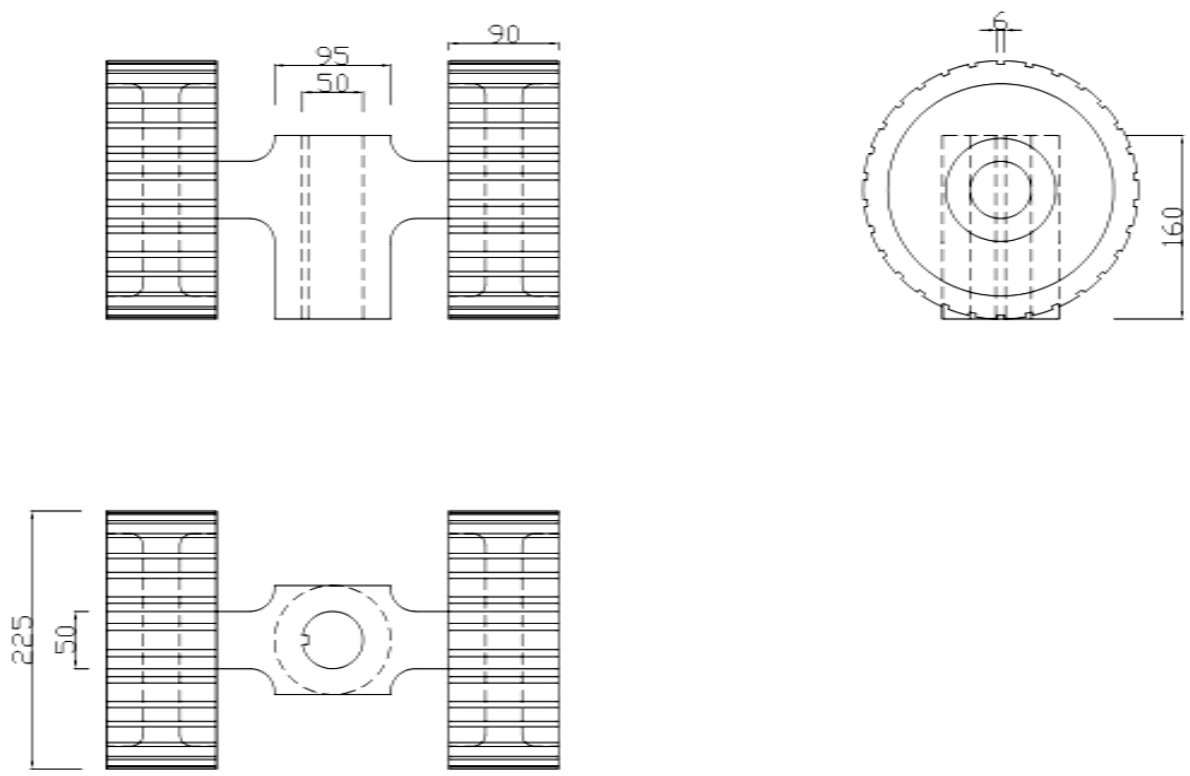

Dim. in $\mathrm{mm}$

Fig. .4. The compressing unit (Rollers) .

\section{The main shaft :-}

The main shaft made from hard steel with dimension as $300 \mathrm{~mm}$ length with extended diameter of $50 \mathrm{~mm}$. The main shaft is fixed in a vertical position and assembled by two bearings. Two bearings with conical shape were assembled in the horizontal location, and the third one in flat shape are located in a vertical location to overcome the torsion stress during pelleting process. With both ends and full of oil bearings the main shaft at the bottom contacted by ring rigid joint with gear box which contactes by electric motor directly .

\section{Cutter knife:-}

The cutter knife made of stainless steel with dimension of $120 \mathrm{~mm}$ in length and $3 \mathrm{~mm}$ in thickness. It assembled on the main shaft directly under the die by cylindrical base which can changing the number of knife to change the product length and takes its motion from the main shaft . The clearance between the cutter knife and the lower surface of the die was $2 \mathrm{~mm}$ to give the suitable length of pellets out from the pressing unit.

\section{Power transmission:-}

The power is transfer from the main motor to rollers through gearbox. The main motor of flat die pellet mill machine has output power of $30 \mathrm{~kW}$ and $1400 \mathrm{rpm}$, 
the main shaft connected with gear box shaft directly to transfer the power from the motor to rollers unit.

\section{Measuring Instruments:}

\section{Digital tachometer:}

Cole- Parmer 8204-00, digital tachometer (kit- Japan) is used for measuring the rotating speed of the main shaft.

\section{Durability turning box:}

A durability turning box consists of four cells rotated at constant speed of 60 rpm and is used to determine pellets durability.

\section{Digital force gauge ( shimpo ):}

digital force gauge was used to determine pellet hardness.

\section{Methods:}

\section{Processing parameters:}

Four different die L/D ratios of ( $5: 1,5.5: 1,6: 1$ and 6.5:1), four mixing retention time of $(2,3.5,4$ and $5 \mathrm{~min})$, using rollers teeth width of $10 \mathrm{~mm}$ were examined as a mechanical parameters and rabbit new formula including black seed meal were examined as physical parameters.

\section{Evaluation of flat die pellet mill efficiency and product quality:}

The pellet mill are evaluated as efficiency and pellets quality on the following measurements:

1- Compatible pellet unit production rate is measured for each treatment by taking sample for $2 \mathrm{~kg}$ after $10 \mathrm{~min}$. of pellet mill running at steady condition

2- Specific mechanical energy (SME), is calculated as the following relation:

$$
\text { Total consumed power },(k W)=\frac{\sqrt{3} I V \eta \cos \theta}{1000}
$$

Where: I = Line current strength in amperes;

$\mathrm{V}=$ Potential difference (Voltage) being equal to $380 \mathrm{~V}$;

$\cos \theta=$ Power factor (being equal to 0.84 ); and

$\eta \quad=$ Mechanical efficiency assumed (90\%);

The SME is.MS, (kW.h/tons) is calculated by the following equation:

$$
\text { Energy consumed }=\frac{P}{Q}=k W . h / \text { ton }
$$

Where:

$\mathrm{P}=$ The consumed power for mixing ration, $\mathrm{kW}$.

$\mathrm{Q}=$ Machinery line productivity, ton/h.

3- Pellet bulk density is calculated for irregular products by the standard methods of . 


$$
\text { Bulk Density }\left(\mathrm{g} / \mathrm{cm}^{3}\right)=\frac{W d}{V d}
$$

Wd: pellets sample mass $(\mathrm{g})$, and

Vd: pellets sample volume $\left(\mathrm{cm}^{3}\right)$

4- Product durability is determined as ASAE standards method, at 3 replicates (mass of each one was $500 \mathrm{~g}$ ) using turning box for $10 \mathrm{~min}$.

$$
\text { Durability }(\%)=\frac{W a}{W b} \times 100
$$

Wa :pellets mass after treatment. ( $\mathrm{g}$ ), and

$\mathrm{Wb}$ : pellets mass before treatment. $(\mathrm{g})$.

5- Mixing efficiency is calculated as the following:

$$
\text { Mixing efficiency }(\%)=\quad \frac{C P A}{C P B} \times 100
$$

Where: $\mathrm{CPA}=$ crude protein after mixing and

$\mathrm{CPB}=$ crude protein before mixing

6- Pellets hardiness: Pellets hardness is measured by digital force gauge.

7- Cost per unit mass: It was calculated from the following formula:-

Cost per unit mass $=\frac{\text { machine } \cos t(L . E / h)}{\text { production }(\text { ton } / h)} \quad$ (L.E/ton $)$

\section{RESULTS AND DISCUSSION}

Evaluation of flat compatible pellet unit performance and product quality are carried out under the following items:.

\section{1- Compatible Pellet unit Productivity:}

Regarding for collected data as shown in Fig(5) it is found that increasing the pre-conditioner retention time from $2 \mathrm{~min}$ to $3.5,4$ and 5 min decreased the pellet mill production from 454.67 to $448.25,442.48$ and $436.7 \mathrm{~kg} / \mathrm{h}$ using die L/D ratio of $5: 1$, from 434.29 to $427.87,422.1$ and $416.32 \mathrm{~kg} / \mathrm{h}$ using die L/D ratio of $5.5: 1$, from 421.4 to $414.98,409.21$ and $403.43 \mathrm{~kg} / \mathrm{h}$ using die L/D ratio of $6: 1$, from 402.56 to $396.14,390.37$ and $384.59 \mathrm{~kg} / \mathrm{h}$ using die L/D ratio of $6.5: 1$.using rollers teeth width of $10 \mathrm{~mm}$ respectively. 


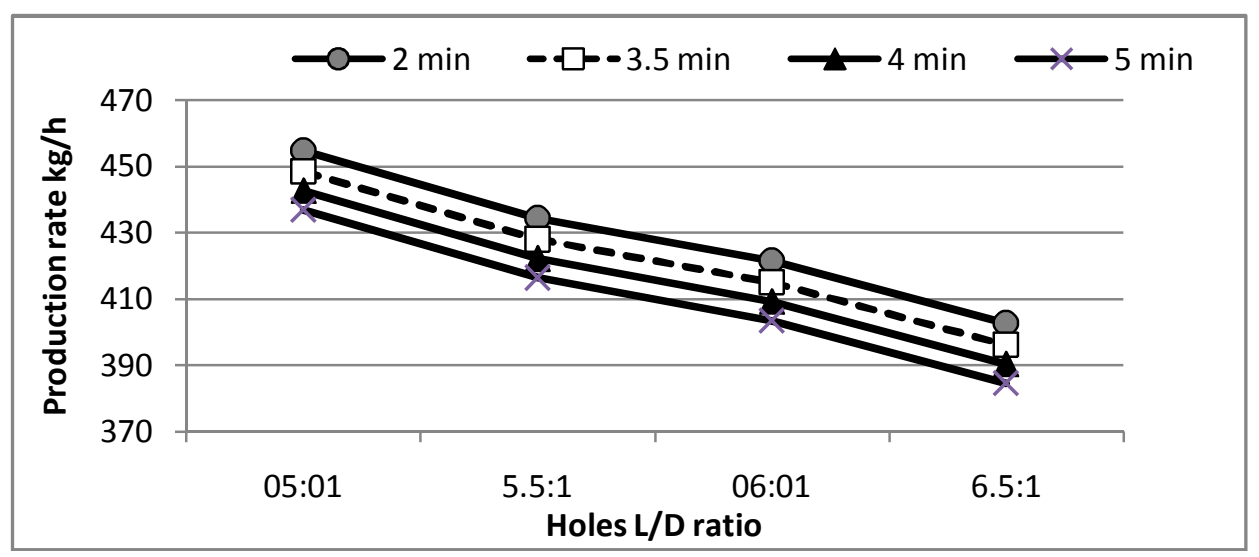

Fig. 5. Effect die L/D ratio on flat die pellet mill productivity using rollers teeth width of $10 \mathrm{~mm}$.

The decrease in flat die production rate by increasing the mixing retention time from 2 to $3.5,4$ and 5 mincould be due to the decrease in pre conditioner shaft speed that lead to decrease the pellet mill feeding mass Also, the decrease in pellet mill production rate by increasing the die L/D ratio from 5:1 to 6.5:1 could be due to the increase in formula retention time inside the die holes that lead to decrease the product output in time unit.

2- Specific mechanical energy (SME): Energy requirements are a very important in economical analysis for any industry.

Is illustrated Regarding for collected data showed in Fig (6) it indicated that increasing the pre-conditioner retention time from $2 \mathrm{~min}$ to $3.5,4$ and $5 \mathrm{~min}$ increasing the energy from 30.53 to $32.99,34.44$ and $35.97 \mathrm{Kw}$.h /ton using die L/D ratio of $5: 1$, from 35.30 to $37.96,39.54$ and $41.22 \mathrm{Kw} . \mathrm{h} /$ ton using die L/D ratio of 5.5:1, from 39.84 to $42.65,44.35$ and $46.15 \mathrm{Kw} . \mathrm{h} /$ ton using die L/D ratio of $6: 1$, from 45.58 to $48.62,50.49$ and $52.47 \mathrm{Kw} . \mathrm{h} /$ ton using die L/D ratio of $6.5: 1$.using rollers teeth width of $10 \mathrm{~mm}$ respectively. 


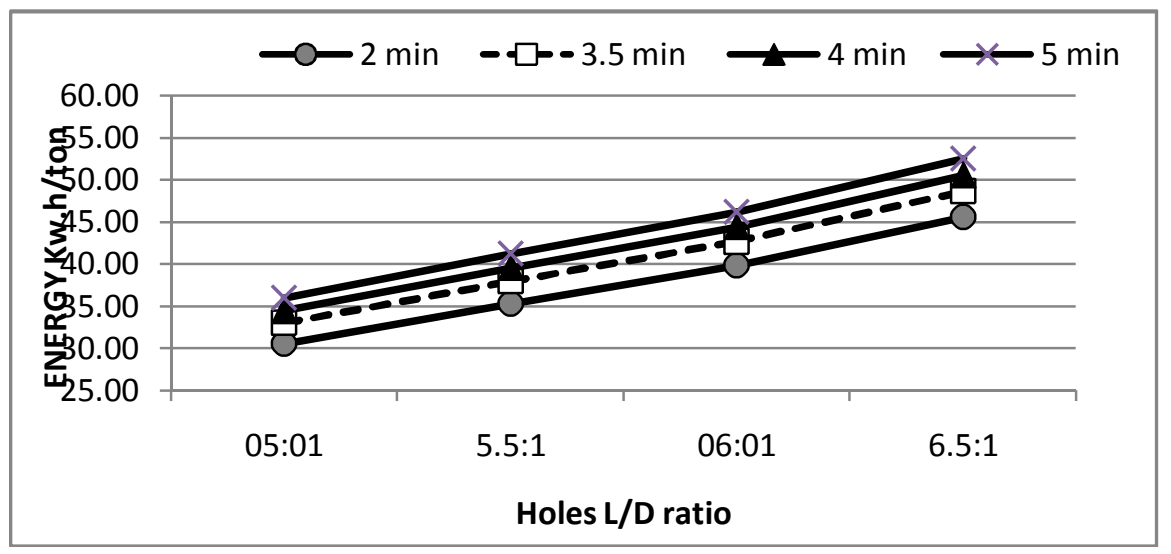

Fig. 6. Effect die L/D ratio, pre-conditioner retention time on energy requirements using rollers teeth width of $10 \mathrm{~mm}$.

\section{3-mixing efficiency:}

Regarding for collected data as shown in Fig (7) it is indicated that using die L/D ratio of 5:1, the pre conditionins retention time increasing from $2 \mathrm{~min}$ to 3.5 and 4 min the mixing efficiency increasing from 85.14 to 87.76 and $90.95 \%$ but it decreased to $88.76 \%$ at the pre conditionins retention time of $5 \mathrm{~min}$, using die L/D ratio of 5.5:1, the pre conditionins retention time increasing from $2 \mathrm{~min}$ to 3.5 and 4 min the mixing efficiency increasing from 85.65 to 88.29 and $91.48 \%$ but it decreased to $89.29 \%$ at the pre conditionins retention time of $5 \mathrm{~min}$, using die L/D ratio of $6: 1$ the pre conditionins retention time increasing from $2 \mathrm{~min}$ to 3.5 and $4 \mathrm{~min}$ the mixing efficiency increasing from 85.77 to 88.4 and $91.59 \%$ but it decreased to $89.39 \%$ at the pre conditionins retention time of $5 \mathrm{~min}$, using die L/D ratio of $6.5: 1$ the pre conditionins retention time increasing from $2 \mathrm{~min}$ to 3.5 and $4 \mathrm{~min}$ the mixing efficiency increasing from 85.82 to 88.43 and $91.62 \%$ but it decreased to $89.45 \%$ at the pre conditionins retention time of $5 \mathrm{~min}$, rollers teeth of $10 \mathrm{~mm}$.using residues formula respectively. 


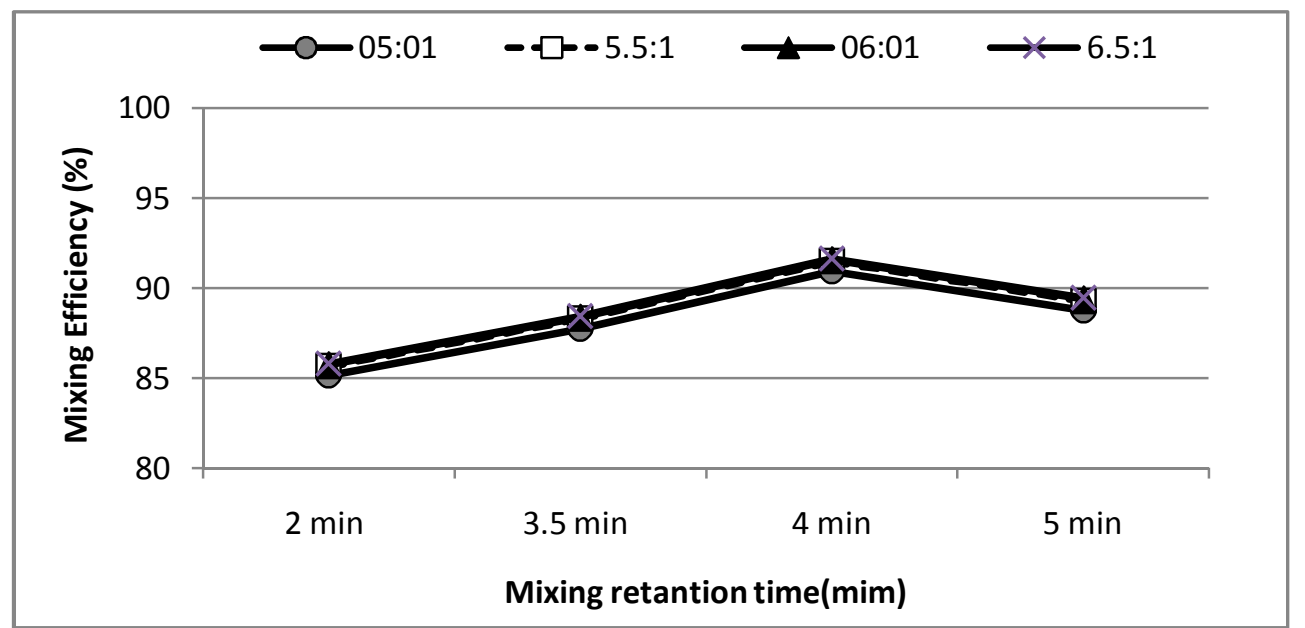

Fig. 7. Effect pre conditionins retention timeonmixing Efficiency using rollers teeth width of $10 \mathrm{~mm}$.

\section{4 -Pellets bulk density:}

Regarding for collected data showed in Fig (8) it is found that using die L/D ratio of $5: 1$ the pre conditionins retention time increasing from $2 \mathrm{~min}$ to $3.5 \mathrm{~min}$ the bulck density increasing from 0.593 to $0.624 \mathrm{~g} / \mathrm{cm} 3$ but it decreased to $0.579,0.56$ $\mathrm{g} / \mathrm{cm} 3$ at the pre conditionins retention time of $4,5 \mathrm{~min}$, using die L/D ratio of 5.5:1 the pre conditionins retention time increasing from $2 \mathrm{~min}$ to $3.5 \mathrm{~min}$ the bulck density increasing from 0.64 to $0.671 \mathrm{~g} / \mathrm{cm} 3$ but it decreased to $0.627,0.607 \mathrm{~g} / \mathrm{cm} 3$ at the pre conditionins retention time of $4,5 \mathrm{~min}$, using die L/D ratio of $6: 1$ the pre conditionins retention time increasing from $2 \mathrm{~min}$ to $3.5 \mathrm{~min}$ the bulck density increasing from 0.684 to $0.715 \mathrm{~g} / \mathrm{cm} 3$ but it decreased to $0.671,0.649 \mathrm{~g} / \mathrm{cm} 3$ at the pre conditionins retention time of $4,5 \mathrm{~min}$, using die $L / D$ ratio of $6.5: 1$ the precondition retention time increasing from $2 \mathrm{~min}$ to $3.5 \mathrm{~min}$ the bulck density increasing from 0.771 to 0.805 $\mathrm{g} / \mathrm{cm} 3$ but it decreased to $0.761,0.741 \mathrm{~g} / \mathrm{cm} 3$ at the pre conditionins retention time of $4,5 \mathrm{~min}$, under rollers teeth of $10 \mathrm{~mm}$ using residues formula respectively. 


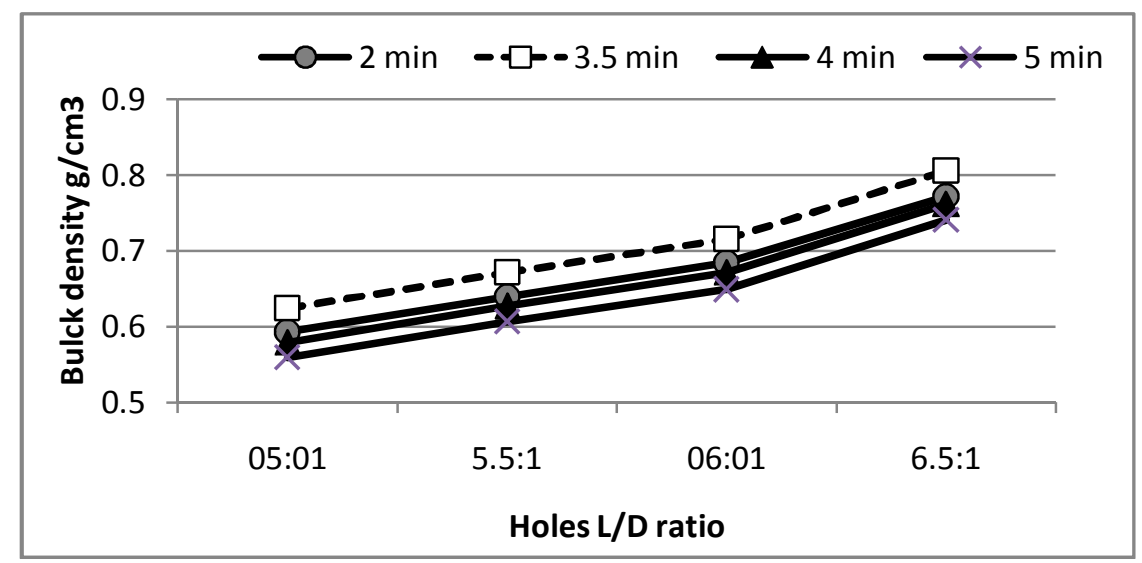

Fig. 8. Effect die L/D ratio, pre-conditioning retention time on bulk density using rollers teeth width of $10 \mathrm{~mm}$.

\section{5-Pellets durability:}

Regarding for collected data showed in Fig (9) it is indicated that using die L/D ratio of 5:1 the pre conditionins retention time increasing from $2 \mathrm{~min}$ to $3.5 \mathrm{~min}$ the pellets durability increasing from 88.3 to $90.72 \%$ but it decreased to $87.97,85.41$ $\%$ at the pre-conditioner retention time of 4,5 min recpictavily, Using die L/D ratio of 5.5:1 the pre-conditioner retention time increase is from $2 \mathrm{~min}$ to $3.5 \mathrm{~min}$ the pellets durability increasing from 90.79 to $93.21 \%$ but it decreased to $90.46,87.9 \%$ at the pre conditionins retention time of 4,5 min recpictavily. As using die L/D ratio of $6: 1$ the pre conditionins retention time increasing from $2 \mathrm{~min}$ to $3.5 \mathrm{~min}$ the pellets durability increases from 91.97 to $94.39 \%$ but it decreased to $91.64,89.08 \%$ at the pre conditionins retention time of 4,5 min recpictavily. Finally using die L/D ratio of $6.5: 1$ the pre conditionins retention time increasing from $2 \mathrm{~min}$ to $3.5 \mathrm{~min}$ the pellets durability increasing from 94.53 to $96.95 \%$ but it decreased to $94.2,91.64 \%$ at the pre conditionins retention time of 4,5 min recpictavily, under rollers teeth of $10 \mathrm{~mm}$ using residues formula . 


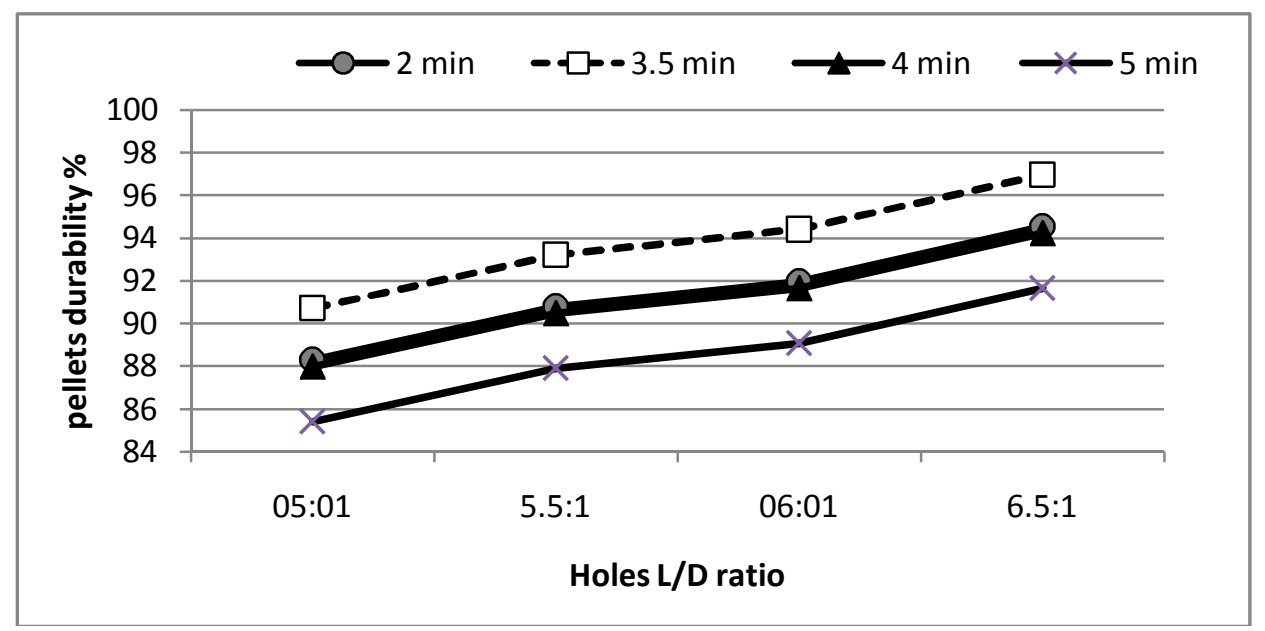

Fig. 9. Effect die L/D ratio, pre-conditioner retention time on pellets durability using rollers teeth width of $10 \mathrm{~mm}$.

\section{6-Pellets hardiness:}

Regarding for collected data showed in Fig (10) is indicated that using die L/D ratio of 5:1, the pre conditionins retention time increases from $2 \mathrm{~min}$ to $3.5 \mathrm{~min}$ the pellets hardness increases from 45.3 to $46.84 \mathrm{~N}$ but it decreased to $44.06,43.86$ $\mathrm{N}$ at the pre conditionins retention time of $4,5 \mathrm{~min}$ recpictavily. Using die L/D ratio of 5.5:1 the pre conditionins retention time increasing from $2 \mathrm{~min}$ to $3.5 \mathrm{~min}$ the pellets hardness increases from 47.47 to $49.01 \mathrm{~N}$ but it decreass to $46.23,46.03 \mathrm{~N}$ at the pre conditionins. As using die L/D ratio of $6: 1$ the pre conditioner retention time increasing from $2 \mathrm{~min}$ to $3.5 \mathrm{~min}$ the pellets hardness increases from 49.5 to $51.04 \mathrm{~N}$ but it decreased to $48.26,48.06 \mathrm{~N}$ at the pre conditionins retention time of $4,5 \mathrm{~min}$ recpictavily.using die $L / D$ ratio of $6.5: 1$ the pre conditionins retention time increasing from $2 \mathrm{~min}$ to $3.5 \mathrm{~min}$ the pellets hardness increases from 56.16 to $57.7 \mathrm{~N}$ but it decreased to $54.92,54.72 \mathrm{~N}$ at the pre conditionins retention time of $4,5 \mathrm{~min}$ recpictavily, under rollers teeth of $10 \mathrm{~mm}$ using residues formula . 


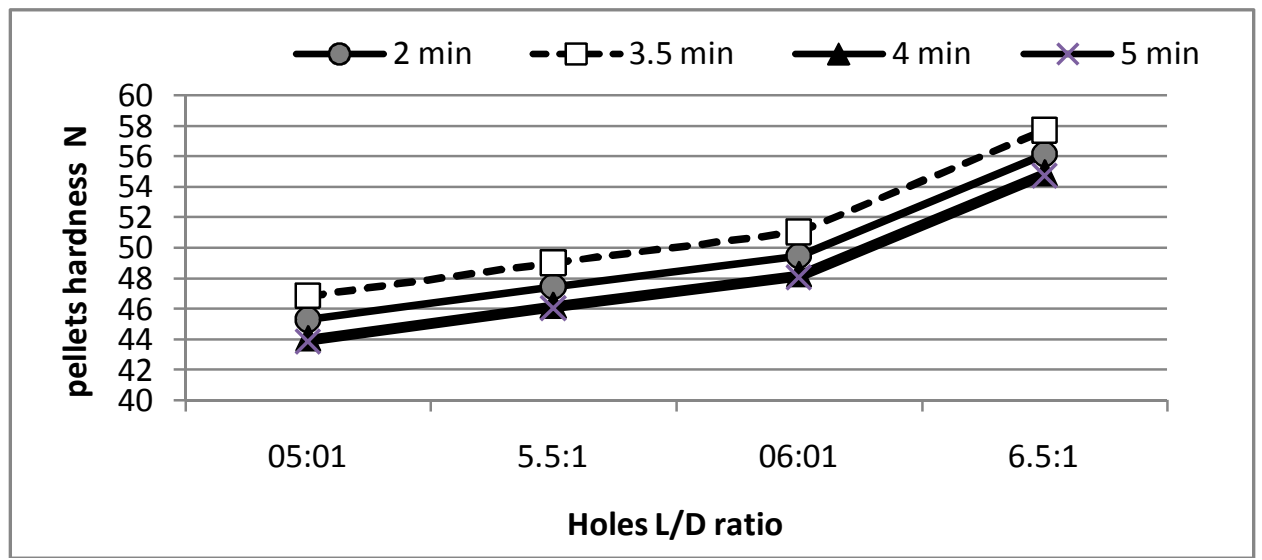

Fig. 10. Effect die L/D ratio, pre-conditioner retention time onpellets hardnessusing rollers teeth width of $10 \mathrm{~mm}$.

7 -Cost of pellets unit mass:It is very important to know what is the advantage of manufacture a simple unit of flat die pelleting machine and use some of residues formulation including black seed meal in rabbits formula economically. as:

Regarding for collected data showed in Fig 11 it is found that increasing the pre conditionins retention time from $2 \mathrm{~min}$ to $3.5,4$ and 5 min increases the cost from 521.85 to $532.96,541.22$ and $553.90 \mathrm{LE} / \mathrm{h}$. Using die L/D ratio of $5: 1$, from 554.24 to $566.36,575.48$ and $589.26 \mathrm{LE} / \mathrm{h}$. As using die L/D ratio of 5.5:1,cost increases from 578.12 to $590.99,600.74$ and $615.32 \mathrm{LE} / \mathrm{h}$. And using die L/D ratio of $6: 1$,cost increases from 623.83 to $638.06,648.97$, and $664.99 \mathrm{LE} / \mathrm{h}$. And finally using die L/D ratio of $6.5: 1$.

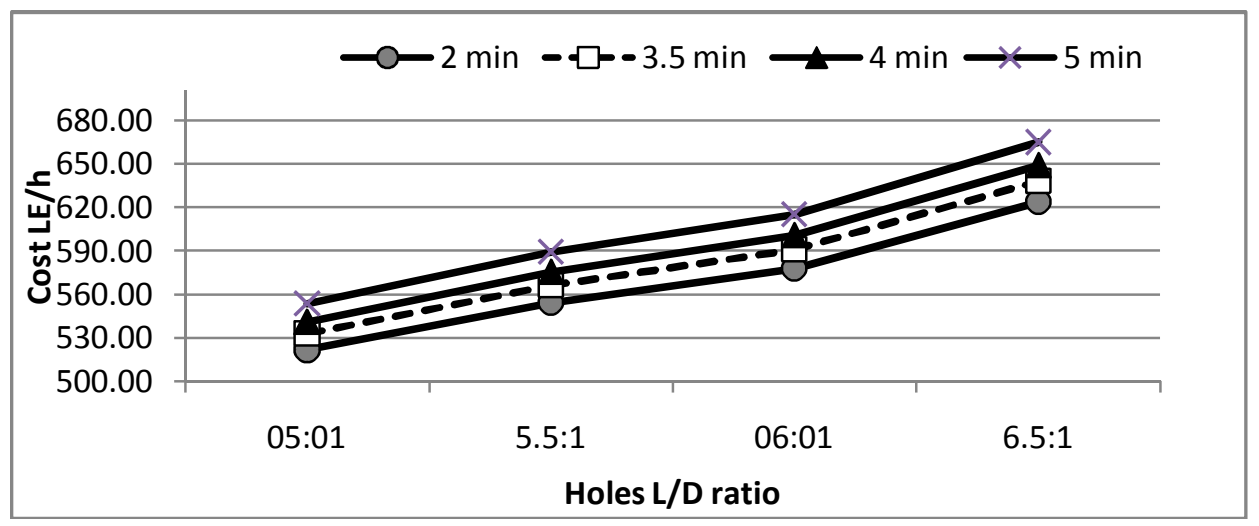

Fig. 11. Effect die L/D ratio, pre-conditioner retention time on cost using rollers teeth width of $10 \mathrm{~mm}$. 


\section{CONCLUSIONS}

The important results obtained data may be summarized in the following recommended points:

1- The preferred die L/D ratio is 5.5:1 for achieving high machine efficiency and pellets quality.

2- $\quad$ The preferred pre-conditioner retention timeis $3.5 \mathrm{~min}$ for high machine efficiency and pellets quality .

\section{REFERENCES}

1. David A.F. 2003. II . Pelleting for profit-parts. National Grain and feed association. Feed and feeding digest, 54 (7): 22

2. Hasting W.H. 2003. Feed milling process. Mt. Vernon, Washington D.Higgs Environment Canda, Van couver, British Colombia.

3. Ismail N. K. 2001. Engineering studies on the processing of some agricultural wastes. Ph.D. Thesis. Fac. of Ag. Mansura Univ

4. Kaddour U.A, T.A., Ewies, M.K. Afify. 2006. Influence of geometrical dimension of extrusion die holes on machine efficiency and pellets quality. 4 annual conference of J. Agric. Sci., MansouraUniv., 31 (7): 337-358.

5. Lee, G., H.E. Huff, and F. Hsieh. 2005. Overall heat transfer coefficient between cooling die and extruded product. Trans of the ASAE ISSN 0001-235 48 (4): 1461-1469.

6. Mcmullen, J., O. Fasina. W. Wood. Y. Fengand, and G. Mills. 2004. Physical characteristics of pellets from poultry litter.ASAE/CSAE Meeting Paper No. 046005. ASAE, St. Joseph, MI. 


\title{
تصنيع وتقييم وحدة مجمعة لإتاج الأعلاف الحيوانية المصبعة
}

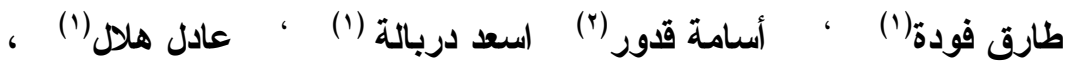

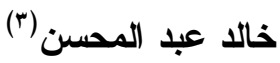

$$
\begin{aligned}
& \text { 1. كلية الزر اعة جامعة طنطا. } \\
& \text { r. كلية الثزوة السمكية جامعة السويس. } \\
& \text { r. معهد بحوث الهندسة الزر اعية - مركز البحوث الزر اعية - الدقى - جيزة. }
\end{aligned}
$$

تهدف الدر اسة إلي تصنيع وتقييم آلة تكعيب أعلاف ذات مشكل أعلاف أفقي لإنتاج أعلاف خاصة الأرانب عالية الجودة. باستخدام مخلفات كسب حبة البركة في التركيبات العلفية. حيث نم

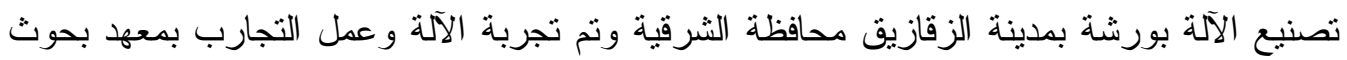

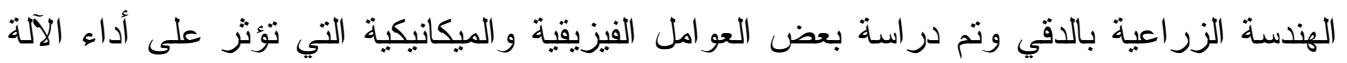

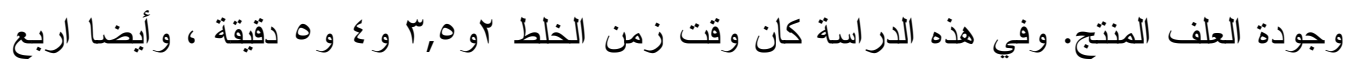

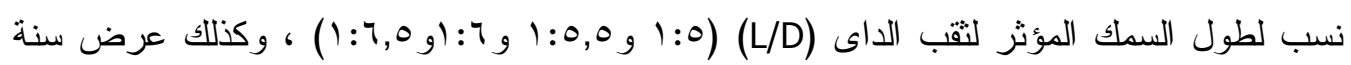

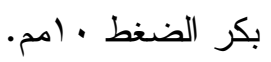

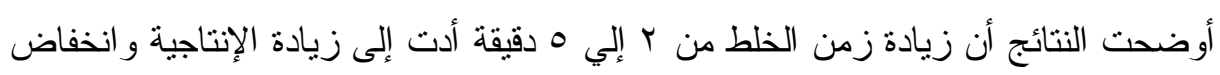

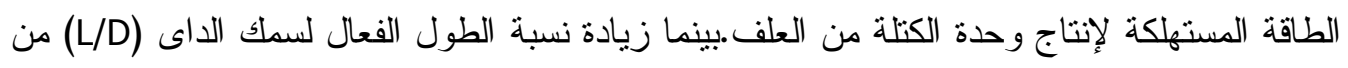
1:0 إلي 1:7,0 أدت إلى انخفاض في الإنتاجية وزيادة مضطردة للطاقة المستهلكة. وعلى الجانب

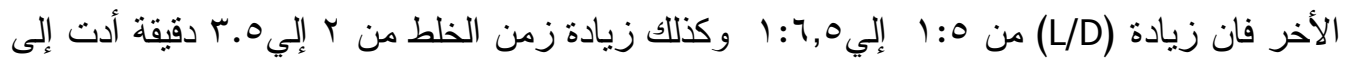
زيادة كثافة العلف ومتانته ومقاو مته للنقل و الصدمات.

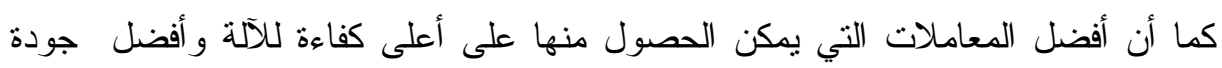

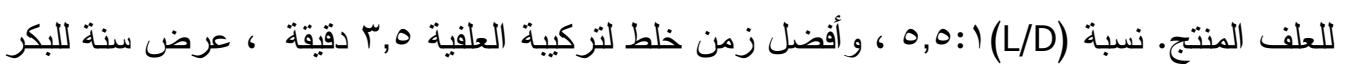

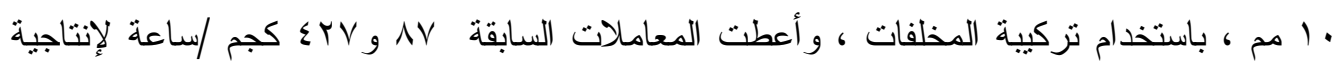

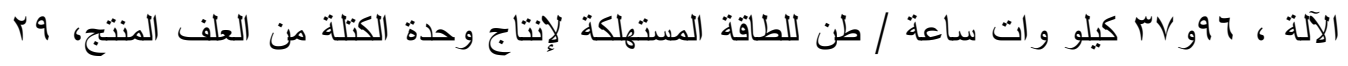

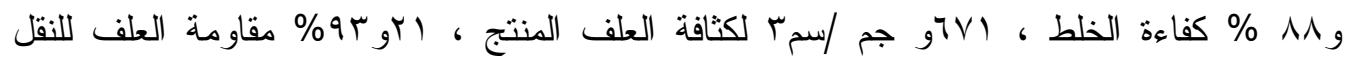

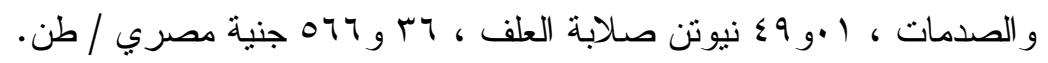

